\title{
The relationship between Helicobacter pylori infection and
}

\section{intestinal parasites in individuals from Khartoum state,}

\section{Sudan: a case-control study [version 1; peer review: 1}

\section{approved, 3 approved with reservations]}

\author{
Yasir Yousif Abd Elbagi ${ }^{1}$, Ahmed Bakheet Abd Alla (iD1, \\ Mohammed Baha Eldin Saad ${ }^{2}$
${ }^{1}$ Department of Parasitology and Medical Entomology, College of Medical Laboratory Science, Sudan University of Science and Technology, Khartoum, Sudan
2Department of Parasitology and Medical Entomology, College of Medical Laboratory Science, Omdurman Ahlia University, \\ Omdurman, Sudan
}

V1 First published: $12 \operatorname{Dec} 2019, \mathbf{8}: 2094$
https://doi.org/10.12688/f1000research.21397.1
Latest published: 18 Jan 2021, 8:2094

https://doi.org/10.12688/f1000research.21397.2

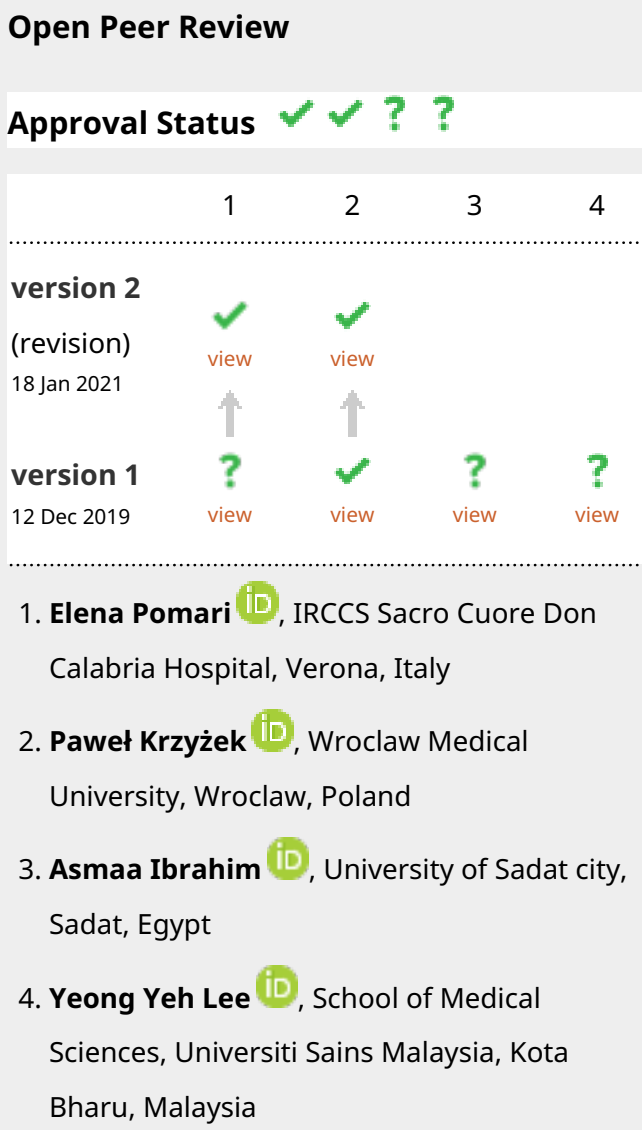

1. Elena Pomari ID, IRCCS Sacro Cuore Don

Calabria Hospital, Verona, Italy

2. Paweł Krzyżek ID , Wroclaw Medical

University, Wroclaw, Poland

3. Asmaa Ibrahim (D), University of Sadat city, Sadat, Egypt

4. Yeong Yeh Lee (iD, School of Medical

Sciences, Universiti Sains Malaysia, Kota

Bharu, Malaysia

Any reports and responses or comments on the article can be found at the end of the article. 
prevalence rate (8\%) was found among the $16-30$ age group.

Conclusion: Together, we found that intestinal parasites are more common in patients with $\mathrm{H}$. pylori. We also noticed that the rate of infection was not affected by gender while the age group was affected.

Keywords

H.pylori, Intestinal parsaite, Khartoum, Alsaha, Yastabsheron.

Corresponding author: Ahmed Bakheet Abd Alla (ahmed.hassanab@gmail.com)

Author roles: Yousif Abd Elbagi Y: Formal Analysis, Investigation; Abd Alla AB: Methodology, Writing - Original Draft Preparation, Writing - Review \& Editing; Saad MBE: Supervision

Competing interests: No competing interests were disclosed.

Grant information: The author(s) declared that no grants were involved in supporting this work.

Copyright: ( $\odot 2019$ Yousif Abd Elbagi Y et al. This is an open access article distributed under the terms of the Creative Commons Attribution License, which permits unrestricted use, distribution, and reproduction in any medium, provided the original work is properly cited.

How to cite this article: Yousif Abd Elbagi Y, Abd Alla AB and Saad MBE. The relationship between Helicobacter pylori infection and intestinal parasites in individuals from Khartoum state, Sudan: a case-control study [version 1; peer review: 1 approved, 3 approved with reservations] F1000Research 2019, 8:2094 https://doi.org/10.12688/f1000research.21397.1

First published: 12 Dec 2019, 8:2094 https://doi.org/10.12688/f1000research.21397.1 


\section{Introduction}

Among the most common diseases in the world are intestinal parasite infections; an estimated 3.5 billion people are affected, and 450 million people are infected (Jayalakshmi \& Dharanidevi, 2016). These infections are considered a serious public health problem as they cause anaemia with iron deficiency, retardation of growth in children, and other physical and mental health problems (Okyay et al., 2004; Tandukar et al., 2013; Wongstitwilairoong et al., 2007). One example is a pathogenic intestinal protozoon that infects the small and/or large intestine (Farthing \& Kelly, 2005), or an intestinal worm, such as Ascaris lumbricoides, Trichuris trichiura, Enterobius vermicularis, and hookworms, which affect people in tropical countries (Smyth, 1990).

Health impacts differ with age: the small intestinal protozoa Giardia lamblia and Cryptosporidium spp. have a serious impact on children (Harhay et al., 2010), while the large intestine pathogen Entamoeba histolytica has a higher morbidity among adults of all ages (Mortimer \& Chadee, 2010). Some protozoa, in particular, Cryptosporidium and Isospora belli, cause significant morbidity in individuals with immunodeficiency (Bachur et al., 2008), for example giardiasis and amoebiasis are opportunistic parasites (Biggs \& Brown, 2001). Helicobacter pylori is the most common chronic human bacterial infection, infecting $70-90 \%$ of the population of developing countries and $25-50 \%$ of the people of developed countries (Gillespie \& Hawkey, 2006). H. pylori colonizes the stomach's mucus layer and induces chronic active gastritis inflammation (Konturek, 2003). It is a major cause of peptic ulcers and a risk factor for gastric malignancies (Lesbros-Pantoflickova et al., 2007).

H. pylori can be easily identified in all microbiology laboratories using simple techniques (Guerrant et al., 2011). Numerous serological diagnostic tests used for the detection of $H$. pylori include bacterial agglutination, complement fixation, indirect immunofluorescence test, enzyme immunoassay, and enzymelinked immunosorbent assay (Kim, 2016). Since H. pylori and intestinal parasites are prevalent in developing countries, this study aimed to determine the prevalence of intestinal parasites in patients with $H$. pylori in Khartoum state.

\section{Methods}

\section{Study design}

This was a case-control study carried out in Khartoum state, Sudan, at Alsaaha Specialized Hospital and Yastabshiron Hospital between 1 June and 27 October 2018. The study was conducted in 100 patients who were $H$. pylori positive as a case group and 100 individuals without $H$. pylori as a control group. The $H$. pylori test had already been performed in hospitals using immuno-chromatographic test (ICT) for identification of $H$. pylori $\mathrm{Ag}$ in stool sample. Participants were divided into groups according to gender and age (see below).

\section{Ethical considerations}

Approval for the study was obtained from the Ethical Authorization Committee (number, MLS-IEC-10-17) of the College of Medical Laboratory Sciences, Sudan University of Science and Technology. Written informed consent for participation and disclosure of data was obtained from each participant in the study and in the case of children $(<18$ years) written informed consent was obtained from their guardians.

\section{Participants}

Individuals in this study who were already being screened for presence of $H$. pylori using ICT for antigen in stool were asked to participate. Individuals with a positive ICT for H. pylori antigen were included in the case group after they agreed to participate in the study, while the control group were those with negative $H$. pylori antigen, who were also only included in the study after they agreed to participate.

\section{Sampling collection}

In total, 200 stool samples were collected from the participants in the study. Samples were collected immediately after participants agreed to partake in the study. Each participant was provided with a labelled stool container (transparent and clean) and was instructed to collect a faecal sample.

\section{Method of stool examination}

Every stool sample was examined for the detection of the intestinal parasite by wet preparation, saturated sodium chloride floatation and formal ether concentration. If one detection method was positive, then the sample was counted as positive for intestinal parasites, even if other methods were negative.

Wet preparation. A small portion of stool was mixed with a drop of normal saline with a wooden applicator stick and deposited on a slide. This was covered with a cover slip and routinely examined under a microscope using $10 \mathrm{X}$ and a high magnification $40 \mathrm{X}$ to detect more parasites, as per the World Health Organization protocol (WHO, 2001).

Formal ether concentration. Approximately $1 \mathrm{~g}$ of faeces from various parts of the stool was collected and emulsified in a glass beaker in $5 \mathrm{ml}$ of formal saline. There a further $5 \mathrm{ml}$ of saline was added and mixed. The resulting suspension was strained using a sieve with small pores. The filtered sample was poured into a centrifugal tube, and an equal volume of ether was added. For one minute, the tube was mixed and then centrifuged at $2000 \mathrm{rpm}$ for 5 minutes. The upper three layers were discarded, and the sediment was moved to a slide, covered with a cover slip and analysed under a microscope using magnifications $10 \mathrm{X}$ and $40 \mathrm{X}$. This was as per the protocol by Smith \& Mank (2011).

Saturated sodium chloride floatation. Approximately a $0.5 \mathrm{~g}$ of faeces was collected from different parts of the stool and emulsified in a long glass tube half-filled with saturated sodium chloride solution. Then the container was filled with sodium chloride until the top of tube. Carefully, a cover glass was put on the top of the tube avoiding air bubbles. After 30 to 45 minutes, the cover glass was removed from the top of the tube and put on a clean and dry slide and examined under the microscope using $10 \mathrm{X}$ and $40 \mathrm{X}$ magnifications. This was as per the protocol by Dryden et al. (2005). 
Data analysis

Statistical analysis was performed using SPSS version 20.0. The Chi-square method was used to compare variables. $\mathrm{P}$ values $<0.05$ were considered statistically significant.

\section{Results}

The results showed that 23 of the 100 patients with $H$. pylori were infected with gastrointestinal parasites (23\%). Of the 100 control individuals, 10 were found to be infected with gastrointestinal parasites (10\%). Between the case and control groups, there was a statistically significant difference in prevalence of intestinal parasites $(P=0.013)$.

Among $H$. pylori patients, the occurrence of intestinal parasites in men and women was similar $(24 \%$ and $22 \%$, respectively; $P=0.841$; Table 1 ). On the other hand, the prevalence of gastrointestinal parasites in men and women in the control group was found to be $9 \%$ and $11 \%$, respectively, but this difference was not statistically significant $(P=0.789$; Table 1).

In the case group, the highest occurrence rates $(40 \%$ and $38 \%$ ) were reported among the 1-15 and 46-60 age groups, while the lowest rate $(10.7 \%)$ was reported among the $31-45$ age group. These differences were not statistically significant $(P$. value $=0.132$; Table 2). For the control group, the highest prevalence rate (15\%) was reported among the 31-45 age group, while the lowest prevalence rate was among the 16-30 age group (8\%). This difference was not statistically significant $(\mathrm{P}=0.528$; Table 2$)$.

The results showed that Entamoeba histolytica was seen in $12 \%$ of $H$. pylori cases followed by Entamoeba coli in $7 \%$ and G. lamblia in $4 \%$ of cases (Table 3). Among the control group E. histolytica was reported at $5 \%$, followed by $G$. lamblia at $3 \%$ and $E$. coli at $2 \%$ (Table 3).

\section{Discussion}

From the study, it is evident that the gastrointestinal parasite overall occurrence among $H$. pylori patients is relatively high $(23 \%)$. It was found that this rate was higher than the published rate by Uğraş \& Miman (2014) in Turkey (7.61\%). As far as the control group is concerned, the overall occurrence rate reported was $10 \%$. This rate is lower than the rate among

Table 1. Occurrence of gastrointestinal parasites among $H$.pylori patients and control individuals according to gender.

\begin{tabular}{|l|l|l|l|l|}
\hline Gender & \multicolumn{2}{|c|}{ N examined } & \multicolumn{2}{c|}{ N positive (\%) } \\
\hline & Case & Control & Case & Control \\
\hline Male & 46 & 54 & $11(24)$ & $5(9)$ \\
\hline Female & 54 & 46 & $12(22)$ & $5(11)$ \\
\hline Total & 100 & 100 & $23(23)$ & $10(10)$ \\
\hline
\end{tabular}

Case difference between groups: $P=0.841$; Control difference between groups: $P=0.789$.

\section{Table 2. Occurrence of gastrointestinal parasites among $\boldsymbol{H}$. pylori patients and control individuals according age group.}

\begin{tabular}{|l|l|l|l|l|}
\hline Age group, years & \multicolumn{2}{|l|}{ N examined } & \multicolumn{2}{|c|}{ N positive (\%) } \\
\hline & Case & Control & Case & Control \\
\hline $1-15$ & 10 & 14 & $4(40)$ & $2(14.3)$ \\
\hline $16-30$ & 37 & 37 & $7(19)$ & $3(8)$ \\
\hline $31-45$ & 28 & 33 & $3(10.7)$ & $5(15)$ \\
\hline $46-60$ & 21 & 12 & $8(38)$ & $0(0)$ \\
\hline $61-75$ & 4 & 4 & $1(25)$ & $0(0)$ \\
\hline Total & 100 & 100 & $23(23)$ & 10 \\
\hline
\end{tabular}

Case difference between age groups: $P=0.132$; Control difference between age groups: $P=0.528$.

Table 3. Occurrence of different gastrointestinal parasites in $\boldsymbol{H}$. pylori patients and control individuals.

\begin{tabular}{|l|l|l|l|l|}
\hline & \multicolumn{2}{|l|}{ N examined } & \multicolumn{2}{l|}{ N positive (\%) } \\
\hline & Case & Control & Case & Control \\
\hline Entamoeba histolytica & 100 & 100 & $12(12)$ & $5(5)$ \\
\hline Giardia lamblia & 100 & 100 & $4(4)$ & $3(3)$ \\
\hline Entamoeba coli & 100 & 100 & $7(7)$ & $2(2)$ \\
\hline
\end{tabular}

H. pylori patients and higher than the rate reported by Uğraş \& Miman (2014). The difference in rates between the control group and patient with $H$. pylori was significant. This, in our opinion, might mean that there is an association between the establishment of gastrointestinal parasites and H. pylori.

The difference in prevalence rates between men and women in H. pylori patients and control individuals was not statistical difference. This finding did not agree with Yakoob et al. (2005), who considered G. lamblia occurrence in Pakistan. That study found a higher rate in men $(72 \%)$ than in women $(28 \%)$.

In our study, the highest occurrences (40\% and 38\%) were reported among the $1-15$ and 46-60 year age groups, respectively, in the $H$. pylori patients, and the 31-45 year age group $(15 \%)$ for the control group. Our finding disagreed with the finding of Fadul et al. (2016), who reported the highest occurrence rate $(50 \%)$ in the age group $>66$ years old. Our results also showed that $E$. histolytica was seen in $12 \%$ of the $H$. pylori cases followed by E. coli in $7 \%$ of cases and G. lamblia in $4 \%$. Lower rates were reported among the control group where E. histolytica was seen in $5 \%$ followed by G. lamblia in $3 \%$ and $E$. coli in $2 \%$. Our result are not in line with the findings of Gökşen et al. (2016) who reported $14.8 \%$ for G. lamblia in the $H$. pylori-positive group, which was in agreement with Escobar-Pardo et al. (2011) who also found a significant association between $H$. pylori and G. lamblia. However, our conclusion was in total disagreement with the finding of Uğraş \& Miman (2014), who reported no significant association 
between $H$. pylori and intestinal parasites in Turkey. This may be due to differences in the study areas with different food and life style of individuals.

\section{Conclusions}

Gastrointestinal parasites are more common among $H$. pylori patients compared to individuals without $H$. pylori; but this infection rate was not affected by gender. The highest infection rate was reported in the $1-15$ and 46-60 age group among $H$. pylori patients and $31-45$ years of age group among the control patients.

\section{Data availability}

Underlying data

Figshare: yasir and ahmed.sav, https://doi.org/10.6084/m9. figshare.10315769.v2 (Abd Alla \& Yousif, 2019).

This project contains the following underlying data:

- Raw data file.sav

- Data dictionary

Data are available under the terms of the Creative Commons Zero "No rights reserved" data waiver (CC0 1.0 Public domain dedication)
Abd Alla A, Yousif Y: yasir and ahmed.sav. figshare. Dataset. 2019. http://www.doi.org/10.6084/m9.figshare.10315769.v2

Bachur TP, Vale JM, Coêlho IC, et al:: Enteric parasitic infections in HIV/AIDS patients before and after the highly active antiretroviral therapy. Braz $\mathrm{J}$ Infect Dis. 2008; 12(2): 115-122.

PubMed Abstract | Publisher Full Text

Biggs B, Brown G: Principles and Practice of Clinical Parasitology. Principles and Practice of Clinical Parasitology. Edited by Stephen H.gillespie and R. D. Pearson. 2001.

Publisher Full Text

Dryden MW, Payne PA, Ridley R, et al:: Comparison of common fecal flotation techniques for the recovery of parasite eggs and oocysts. Vet Ther. 2005; 6(1) 15-28.

PubMed Abstract

Escobar-Pardo ML, de Godoy AP, Machado RS, et al:: Prevalence of Helicobacter pylori infection and intestinal parasitosis in children of the Xingu Indian Reservation. J Pediatr (Rio J). 2011; 87(5): 393-8.

PubMed Abstract | Publisher Full Text

Fadul N, Ahmed M, Elamin T, et al.: Prevalence Rate Of Giardia Lamblia I Helicobacter pylori Co-Infections In Khartoum State, Sudan. International Journal of Scientific \& Technology Research. 2016; 5(3): 181-190.

Reference Source

Farthing MJ, Kelly P: Protozoal gastrointestinal infections. Medicine. 2005; 33(4): 81-83.

Publisher Full Tex

Gillespie SH, Hawkey PM: Principles and Practice of Clinical Bacteriology Second Edition. Principles and Practice of Clinical Bacteriology. 2006. Publisher Full Text

Gökşen B, Appak YÇ, Girginkardesler N, et al:: Coexistence of Helicobacter pylori and Intestinal Parasitosis in Children with Chronic Abdominal Pain Turkiye Parazitol Derg. 2016; 40(1): 32-6.

PubMed Abstract | Publisher Full Text

Guerrant RL, Walker DH, Weller PF: Tropical infectious diseases: principles, pathogens and practice. third edit. Elsevier Inc. 2011.

Publisher Full Text

Harhay MO, Horton J, Olliaro PL: Epidemiology and control of human gastrointestinal parasites in children. Expert Rev Anti Infect Ther. 2010; 8(2): 219-234.

PubMed Abstract | Publisher Full Text | Free Full Text

Jayalakshmi S, Dharanidevi S: The Prevalence of Intestinal Parasitic Infections in a tertiary care hospital in southern India-A retrospective study. Int $J$ Curr
Microbiol App Sci. 2016; 5(10): 718-23.

Publisher Full Text

Kim N: Helicobacter pylori. Edited by N. Kim. Springer Nature. 2016. Publisher Full Text

Konturek JW: Discovery by Jaworski of Helicobacter pylori and its pathogenetic role in peptic ulcer, gastritis and gastric cancer. $J$ Physio Pharmacol. 2003; 54 Suppl 3: 23-41.

PubMed Abstract

Lesbros-Pantoflickova D, Corthésy-Theulaz I, Blum AL: Helicobacter pylori and probiotics. J Nutr. 2007; 137(3 Suppl 2): 812S-8S

PubMed Abstract | Publisher Full Text

Mortimer L, Chadee K: The immunopathogenesis of Entamoeba histolytica. Exp Parasitol. 2010; 126(3): 366-380.

PubMed Abstract | Publisher Full Text

Okyay P, Ertug S, Gultekin B, et al.: Intestinal parasites prevalence and related factors in school children, a western city sample--Turkey. BMC Public Health. 2004; 4 : 64

PubMed Abstract | Publisher Full Text | Free Full Text

Smith HV, Mank TG: Diagnosis of human giardiasis. In Giardia. Springer, Vienna. 2011; 353-377.

Publisher Full Tex

Smyth JD: Foundations of parasitology (4th edn). 8th edn, Parasitology Today. 8th edn. Edited by P. E. Reidy. Americas, New York: Janice Roerig-Blong. 1990. Publisher Full Text

Tandukar S, Ansari S, Adhikari N, et al:: Intestinal parasitosis in school children of Lalitpur district of Nepal. BMC Res Notes. 2013; 6(1): 449.

PubMed Abstract | Publisher Full Text | Free Full Text

Uğraş M, Miman O: [The prevalence of intestinal parasites in children with Helicobacter pylori gastritis evaluated retrospectively]. Turkiye Parazitol Derg. 2014; 37(4): 245-248.

PubMed Abstract | Publisher Full Text

Wongstitwilairoong B, Srijan A, Serichantalergs $\mathrm{O}$, et al:: Intestinal parasitic infections among pre-school children in Sangkhlaburi, Thailand. Am J Trop Med Hyg. 2007; 76(2): 345-350.

PubMed Abstract | Publisher Full Tex

World Health Organization: Guidelines on standard operating procedures for laboratory diagnosis of HIV-oportunistic infections (No. SEA-HLM-332). WHO Regional Office for South-East Asia. 2001.

Reference Source

Yakoob J, Jafri W, Abid S, et al:: Giardiasis in patients with dyspeptic symptoms. World J Gastroentrol. 2005; 11(42): 6667-6670.

PubMed Abstract | Publisher Full Text | Free Full Text 


\section{Open Peer Review}

\section{Current Peer Review Status: ? $\checkmark$ ?}

\section{Version 1}

Reviewer Report 10 August 2020

https://doi.org/10.5256/f1000research.23567.r67155

(C) $\mathbf{2 0 2 0}$ Lee $\mathbf{Y}$. This is an open access peer review report distributed under the terms of the Creative Commons Attribution License, which permits unrestricted use, distribution, and reproduction in any medium, provided the original work is properly cited.

\section{Yeong Yeh Lee}

Department of Medicine, School of Medical Sciences, Universiti Sains Malaysia, Kota Bharu, Malaysia

The study adds to a body of literature supporting the common presence of $H$. pylori and intestinal parasites co-infection. There are several concerns as below:

1. Best if the study design involved age and gender-matched cohorts. Case-control might be biased especially selection bias.

2. Sample size calculation - how 100 samples each arm is decided?

3. Ideally, two serological tests for H. pylori are needed to confirm infection.

4. Only limited parasites were detected. Please provide explanations.

5. Please discuss reasons for co-infection of detected parasites with H. pylori, the significance, and discuss the age group differences found between current study and others.

\section{References}

1. Hussain Z, El-Omar E, Lee Y: Dual infective burden of Helicobacter pylori and intestinal parasites: Good or bad news for the host?. Indian Journal of Gastroenterology. 2020; 39 (2): 111-116 Publisher

Full Text

Is the work clearly and accurately presented and does it cite the current literature? Partly

Is the study design appropriate and is the work technically sound? Partly

Are sufficient details of methods and analysis provided to allow replication by others? 
Yes

If applicable, is the statistical analysis and its interpretation appropriate? Partly

Are all the source data underlying the results available to ensure full reproducibility? Yes

Are the conclusions drawn adequately supported by the results? Partly

Competing Interests: No competing interests were disclosed.

Reviewer Expertise: Helicobacter pylori, gut microbiota, gastrointestinal cancers

I confirm that I have read this submission and believe that I have an appropriate level of expertise to confirm that it is of an acceptable scientific standard, however I have significant reservations, as outlined above.

Reviewer Report 27 July 2020

https://doi.org/10.5256/f1000research.23567.r67158

(C) 2020 Ibrahim A. This is an open access peer review report distributed under the terms of the Creative Commons Attribution License, which permits unrestricted use, distribution, and reproduction in any medium, provided the original work is properly cited.

\section{Asmaa Ibrahim}

Department of Molecular biology, Genetic Engineering and Biotechnology Research Institute, University of Sadat city, Sadat, Egypt

The article aims to evaluate the prevalence rate of intestinal parasites in $\mathrm{H}$. pylori positive patients in a specific state in Sudan.

\section{Major revision:}

1. The introduction needs to be more updated (ex. Haque (2007) and Nyantekyi et al., (2010) instead of (Smyth, 1990), both articles associated with helminthic infections in developing countries.

2. In the method of stool examination part, I prefer to make also examination with acid-fast stain (AF), in case of diarrhea or immunodeficiency to detect coccidian parasites.

3. In data analysis part, if there are any data about socio-demographic characteristics such as (residency in rural or urban areas, animal contact, and water source) and clinical symptoms such as (diarrhea, vomiting and fever) were collected, I prefer to analyze its association with the infection as estimated risk factors (multivariate logistic regression, 95\% CI and OR). 
4. The current study associated with the " developing countries" especially Sudan, while the discussion is focused on studies conducted a specific country "Turkey", which mainly not considered as a developing country. I prefer to compare the present study with other studies in Egypt (10.1007/s12639-018-1075-y $\left.{ }^{1}\right)$, Iran (10.5812/pedinfect.15294²) and Ethiopia

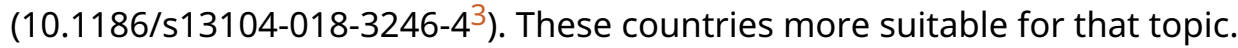

\section{References}

1. Ibrahim A, Ali YBM, Abdel-Aziz A, El-Badry AA: Helicobacter pylori and enteric parasites coinfection among diarrheic and non-diarrheic Egyptian children: seasonality, estimated risks, and predictive factors.J Parasit Dis. 2019; 43 (2): 198-208 PubMed Abstract | Publisher Full Text 2. Kazemian H, Shavalipour A, Mohebi R, Ghafurian S, et al.: Estimation of the Parasitic Infection Prevalence in Children With Helicobacter pylori Infection in Ilam City (2012-2013). Archives of Pediatric Infectious Diseases. 2014; 2 (1). Publisher Full Text

3. Seid A, Tamir Z, Kasanew B, Senbetay M: Co-infection of intestinal parasites and Helicobacter pylori among upper gastrointestinal symptomatic adult patients attending Mekanesalem Hospital, northeast Ethiopia.BMC Res Notes. 2018; 11 (1): 144 PubMed Abstract | Publisher Full Text

Is the work clearly and accurately presented and does it cite the current literature? Partly

Is the study design appropriate and is the work technically sound? Yes

Are sufficient details of methods and analysis provided to allow replication by others? Yes

If applicable, is the statistical analysis and its interpretation appropriate? Partly

Are all the source data underlying the results available to ensure full reproducibility? Yes

Are the conclusions drawn adequately supported by the results? Yes

Competing Interests: No competing interests were disclosed.

Reviewer Expertise: Infectious diseases, mostly focused on $\mathrm{H}$. pylori and Cryptosporidium

I confirm that I have read this submission and believe that I have an appropriate level of expertise to confirm that it is of an acceptable scientific standard, however I have significant reservations, as outlined above. 


\section{https://doi.org/10.5256/f1000research.23567.r67152}

(c) 2020 Krzyżek P. This is an open access peer review report distributed under the terms of the Creative Commons Attribution License, which permits unrestricted use, distribution, and reproduction in any medium, provided the original work is properly cited.

\section{Paweł Krzyżek}

Department of Microbiology, Wroclaw Medical University, Wroclaw, Poland

The article is a short report which aims to show the higher frequency of selected parasites in $H$. pylori-positive patients. I believe the manuscript is worth indexing, however, I suggest to apply two corrections:

I think that it would be easier for readers to give p-values in tables as an independent column (this way it will be easy to read which results are statistically different from each other).

I believe that the discussion should be extended to the immunological part, even though it was not the aim of this article. The results obtained by the Authors indicate a higher frequency of parasites in $H$. pylori-positive patients aged 1-15 and 46-60. These results indicate that an immature/weakened immune system may influence the parasite- $H$. pylori relationship in the host. Thus, I suggest that the Authors should discuss this topic and add relevant literature references.

Is the work clearly and accurately presented and does it cite the current literature? Partly

Is the study design appropriate and is the work technically sound?

Yes

Are sufficient details of methods and analysis provided to allow replication by others? Yes

If applicable, is the statistical analysis and its interpretation appropriate? Partly

Are all the source data underlying the results available to ensure full reproducibility? Yes

Are the conclusions drawn adequately supported by the results? Yes

Competing Interests: No competing interests were disclosed.

Reviewer Expertise: Microbiology, mostly focused on $\mathrm{H}$. pylori

I confirm that I have read this submission and believe that I have an appropriate level of expertise to confirm that it is of an acceptable scientific standard. 
Reviewer Report 15 July 2020

https://doi.org/10.5256/f1000research.23567.r67157

(C) 2020 Pomari E. This is an open access peer review report distributed under the terms of the Creative Commons Attribution License, which permits unrestricted use, distribution, and reproduction in any medium, provided the original work is properly cited.

\section{Elena Pomari}

Department of Infectious-Tropical Diseases and Microbiology, IRCCS Sacro Cuore Don Calabria Hospital, Verona, Italy

Authors describe the occurrence of $H$. pylori and intestinal parasites concomitant infections in individuals from a specific state in Sudan.

\section{Major revision:}

1. .The rationale of the study is focused on the "in developing countries" and the discussion is mostly on studies conducted in Turkey. To the best of my knowlegde, the current (or recent) Turkey GDP is not so low. Thus, authors should compare their findings with other available data reported in studies conducted for example in Egypt, Ethiopia ... (doi: 10.12816/0010855 1; 10.1186/s13104-018-3246-4², etc).

2. In the discussion, authors conclude suggesting that different food and life style of individuals among different geo regions might determine various occurrence of infections. Did authors have any information about diet, life style of the included subjects? These Minor revision: variables could be added in tables and analysis.

1. Keywords: check typing for "Intestinal parsaite" and "Yastabsheron"

\section{References}

1. Sabah AA, Gneidy MR, Saleh NM: Prevalence of Helicobacter pylori infection among adult patients with different gastrointestinal parasites in Tanta City district.J Egypt Soc Parasitol. 2015; 45 (1): 101-6 PubMed Abstract | Publisher Full Text

2. Seid A, Tamir Z, Kasanew B, Senbetay M: Co-infection of intestinal parasites and Helicobacter pylori among upper gastrointestinal symptomatic adult patients attending Mekanesalem Hospital, northeast Ethiopia.BMC Res Notes. 2018; 11 (1): 144 PubMed Abstract | Publisher Full Text

Is the work clearly and accurately presented and does it cite the current literature? Partly

Is the study design appropriate and is the work technically sound? Yes

Are sufficient details of methods and analysis provided to allow replication by others? Yes 
If applicable, is the statistical analysis and its interpretation appropriate? Yes

Are all the source data underlying the results available to ensure full reproducibility? Yes

Are the conclusions drawn adequately supported by the results? Partly

Competing Interests: No competing interests were disclosed.

Reviewer Expertise: Infectious diseases

I confirm that I have read this submission and believe that I have an appropriate level of expertise to confirm that it is of an acceptable scientific standard, however I have significant reservations, as outlined above.

The benefits of publishing with F1000Research:

- Your article is published within days, with no editorial bias

- You can publish traditional articles, null/negative results, case reports, data notes and more

- The peer review process is transparent and collaborative

- Your article is indexed in PubMed after passing peer review

- Dedicated customer support at every stage

For pre-submission enquiries, contact research@f1000.com 